\title{
RELATIONSHIP BETWEEN SERUM URIC ACID LEVELS AND SLEEP-RELATED BREATHING DISORDERS IN OBESE SUBJECTS
}

\author{
OBEZ OLGULARDA ÜRIK ASIT DÜZEYININ UYKUDA SOLUNUM BOZUKLUKLARI \\ ILE ILIŞKISI
}

\author{
Aylin PIHTILI' (D), Züleyha BINGÖL ${ }^{1}$ (D), Esen KIYAN ${ }^{1}$ \\ ${ }^{1}$ Istanbul University, Istanbul Faculty of Medicine, Department of Pulmonary Medicine, Istanbul, Turkey
}

ORCID IDs of the authors: A.P. 0000-0001-8846-048X; Z.B. 0000-0002-1414-617X; E.K. 0000-0003-0023-6518

Cite this article as: Pihtili A, Bingol Z, Kiyan E. Relationship between serum uric acid levels and sleep-related breathing disorders in obese subjects. J Ist Faculty Med 2021;84(2):208-13. doi: 10.26650/IUITFD.2020.822959

\begin{abstract}
Objective: We examined the serum uric acid (UA) levels among patients with sleep-related breathing disorders (SRBD) and the relationship between UA levels and obstructive sleep apnea (OSA) severity, nocturnal hypoxemia (NH) and obesity hypoventilation syndrome (OHS).
\end{abstract}

Material and Method: Subjects with body mass index (BMI) $\geq 30$ $\mathrm{kg} / \mathrm{m}^{2}$ who, according to polysomnography results, have SRBD were included. Demographics, anthropometric measurements and serum UA were recorded. The apnea-hypopnea index (AHI) and oxygen desaturation index (ODI) were recorded. The OSA severity was graded as mild (AHI 5-14 events/hour), moderate (AHI 15-29 events/hour) or severe ( $\mathrm{AHI} \geq 30$ events/hour). NH was considered when sleep time spent with $\mathrm{SpO}_{2}<90 \%$ was $\geq 30 \%$. $\mathrm{PaCO}_{2}>45 \mathrm{mmHg}$ was considered OHS.

Results: The study included 159 patients with SRBD (79 female, 80 males, age: $50.0 \pm 10.5$ years, BMI: $\left.40.1 \pm 5.7 \mathrm{~kg} / \mathrm{m}^{2}\right)$. Seventy-six had OHS and 83 had pure OSA. NH was detected in $25.8 \%$ of patients. UA levels were higher in subjects with $\mathrm{NH}(6.22 \pm 1.37$ $\mathrm{mg} / \mathrm{dl}, 5.67 \pm 1.51 \mathrm{mg} / \mathrm{dl}, \mathrm{p}=0.008)$. UA levels were similar in patients with $\mathrm{OHS}$ and pure OSA $(5.91 \pm 1.25 \mathrm{mg} / \mathrm{dl}, 5.72 \pm 1.68 \mathrm{mg} /$ $\mathrm{dl}, \mathrm{p}=0.1)$. UA levels increased as OSA severity increased (mild: $5.03 \pm 1.41 \mathrm{mg} / \mathrm{dl}$, moderate: $5.46 \pm 1.55 \mathrm{mg} / \mathrm{dl}$, severe: $6.19 \pm 1.8$ $\mathrm{mg} / \mathrm{dl}, \mathrm{p}=0.039)$. UA levels were higher in males with OSA $(6.86 \pm 1.64 \mathrm{mg} / \mathrm{dl}, 4.84 \pm 1.10 \mathrm{mg} / \mathrm{dl}, \mathrm{p}<0.001)$. UA levels were correlated with neck circumference $(r=0.366, p<0.001)$, waist/ hip ratio $(r=0.358, p<0.001)$, OSA severity $(r=0.224, p=0.005)$, $\mathrm{AHI}(r=0.250, p=0.001)$, ODI $(r=291, p<0.001)$ and sleep time with $\mathrm{SpO}_{2}<90 \%(r=0.228, p=0.004)$. Male gender, waist/hip ratio and $\mathrm{NH}$ were factors independently related with UA levels (retrospectively; $p<0.001, p=0.03, p=0.03$ ).

Conclusion: In obese subjects with SRBD, serum UA levels were associated with male gender, $\mathrm{NH}$ and OSA severity.

Keywords: Nocturnal hypoxemia, obesity, obesity hypoventilation syndrome, obstructive sleep apnea, uric acid

\section{ÖZET}

Amaç: Bu çalışmada obez ve uyku ile ilişkili solunum bozuklukları (UISB) olan olgularda serum ürik asit (ÜA) düzeyinin obstruktif uyku apne (OUA) şiddeti, nokturnal hipoksemi $(\mathrm{NH})$ ve obezite hipoventilasyon sendromu (OHS) ile ilişkisi araştırıldı.

Gereç ve Yöntem: Uyku laboratuarına başvuran vücut kitle indeksi (VKI) $\geq 30 \mathrm{~kg} / \mathrm{m}^{2}$ olan polisomnografi ile UiSB saptanan tüm olgular çalışmaya alındı. Demografik özellikler, antropometrik ölçümler ve serum ÜA düzeyleri kaydedildi. Apne-hipopne indeksi (AHi) ve ODi (oksijen desaturasyon indeksi) hesaplandı. AHI 5-14 olay/sa hafif, 15-29 olay/sa orta ve $\geq 30$ olay/sa ağır şiddette OUA olarak değerlendirildi. Nokturnal $\mathrm{SpO}_{2}<\% 90$ olan sure $\geq \% 30$ ise $\mathrm{NH}$ kabul edildi. $\mathrm{PaCO}_{2}>45 \mathrm{mmHg}$ ise $\mathrm{OHS}$ tanısı koyuldu.

Bulgular: Çalışmaya 159 UiSB olan olgu (79 kadın, 80 erkek, yaş: 50,0 $\pm 10,5 \mathrm{yıl}, \mathrm{VKI}: 40,1 \pm 5,7 \mathrm{~kg} / \mathrm{m}^{2}$ ) dahil edildi. Olguların 76'sında OHS ve 83'ün de saf OUA tanısı mevcuttu. NH \%25,8'inde ( $n=41)$ saptandı. NH olanlarda ÜA düzeyi anlamlı olarak yüksekti $(6,22 \pm 1,37 \mathrm{mg} / \mathrm{dl}, 5,67 \pm 1,51 \mathrm{mg} / \mathrm{dl}, \mathrm{p}=0,008)$. OHS olgularında ÜA düzeyi saf OUA olguları ile benzerdi $(5,91 \pm 1,25$ $\mathrm{mg} / \mathrm{dl}, 5,72 \pm 1,68 \mathrm{mg} / \mathrm{dl}, \mathrm{p}=0,1)$. OUA şiddeti arttıkça ÜA dü-

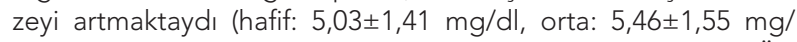
dl, ağır: $6,19 \pm 1,8 \mathrm{mg} / \mathrm{dl}, \mathrm{p}=0,039)$. Erkek OUA olgularında ÜA düzeyleri daha yüksekti $(6,86 \pm 1,64 \mathrm{mg} / \mathrm{dl}, 4,84 \pm 1,10 \mathrm{mg} / \mathrm{dl}$, $p<0,001)$. ÜA düzeyi boyun çevresi $(r=0,366, p<0,001)$, bel/kalça oranı $(r=0,358, p<0,001)$, OUA şiddeti $(r=0,224, p=0,005)$, AHI $(r=0,250, p=0,001)$, ODi $(r=291, p<0,001)$, nokturnal $\mathrm{SpO}_{2}<\% 90$ geçen süre $(r=0,228, p=0,004)$ ile korelasyon göstermekteydi. Erkek cinsiyet, $\mathrm{NH}$ ve bel/kalça oranı ÜA düzeyi ile bağımsız ilişkili faktörler olarak bulundu (sırasıyla; $p<0,001, p=0,03, p=0,03$ ).

Sonuç: UiSB olan obez olgularda, yüksek serum ÜA düzeyleri erkek cinsiyet, NH ve OUA şiddeti ile ilişkili bulunmuştur.

Anahtar Kelimeler: Nokturnal hipoksemi, obezite, obezite hipoventilasyon sendromu, obstruktif uyku apne, ürik asit

Corresponding author/iletişim kurulacak yazar: draylin02@yahoo.com

Submitted/Başvuru: 10.05.2020 • Revision Requested/Revizyon Talebi: 17.09.2020 •

Last Revision Received/Son Revizyon: 25.12.2020 • Accepted/Kabul: 03.01.2021 • Published Online/Online Yayın: 01.04 .2021 


\section{INTRODUCTION}

Sleep-related breathing disorders (SRBD) are a group of diseases that may include nocturnal hypoxemia (NH) such as obstructive sleep apnea (OSA) and obesity hypoventilation syndrome (OHS) (1). NH may lead to hyperuricemia by causing tissue hypoxia (1-3). Higher levels of serum uric acid have been shown to be associated with increased risk of hypertension, diabetes mellitus, peripheral artery disease and cardiovascular disease through systemic inflammation (4-7). It is known that SRBD are associated with obesity, systemic inflammation, hypertension and increased risk of cardiovascular diseases (1, 8-12). There are several previous studies that investigate the relationship between serum uric acid and OSA (1325). However, studies evaluating the relationship between severity of OSA, $\mathrm{NH}$ and hyperuricemia are limited $(14,15,19)$. Also, there is no study in the literature investigating the relationship between serum uric acid levels and OHS. Therefore, in this study we investigated the serum uric acid levels among patients with SRBD, as well as the relationship between uric acid levels and severity of $\mathrm{OSA}, \mathrm{NH}$ and $\mathrm{OHS}$.

\section{MATERIAL AND METHOD}

This study evaluated adult subjects with a body mass index (BMI) $\geq 30 \mathrm{~kg} / \mathrm{m}^{2}$ who were admitted to the sleep laboratory. Patients who were diagnosed as SRBD with polysomnography were included in the study. The exclusion criteria were presence of obstructive [Forced expiratory volume 1. second $\left(\mathrm{FEV}_{1}\right) /$ Forced vital capacity $(\mathrm{FVC})$ ratio $\left.<70 \%\right]$ or restrictive pulmonary diseases except obesity (FVC $<80 \%$ ), left heart failure, renal failure, gout disease, total sleep time less than four hours and drug usage affecting sleep architecture or uric acid levels (thiazids, loop diuretics, allopurinol or aspirin). Demographics, anthropometric measurements (neck circumference, waist/hip ratio), and comorbidities were recorded. Khosla and Lowe's formula (weight $[\mathrm{kg}] /$ height $^{2}\left[\mathrm{~m}^{2}\right]$ ) was used to calculate the BMI. Neck circumference was measured at the level of the cricothyroid membrane. Waist circumference was measured from the midpoint of the last rib to the top of the iliac crest. Hip circumference was measured at the widest portion of the buttocks. Polysomnography, spirometry and arterial blood gas analysis (ABG) in the daytime were performed on all patients. Spirometry (ZAN 74N, Sydney, Australia) was performed according to approved standards (26). ABG analysis (Radiometer ABL 5, Copenhagen, Denmark) was performed after 15 minutes of rest in room air.

All-night polysomnography records were scored by a trained technician according to the American Academy of Sleep Medicine 2013 guidelines (27). The apnea-hypopnea index (AHI) and oxygen desaturation index (ODI) were recorded. OSA was diagnosed if the $\mathrm{AHI}$ was $\geq 5 /$ hour with the presence of clinical symptoms or the $\mathrm{AHI}$ was $\geq 15 /$ hour without any symptoms. The OSA severity was graded as mild (AHI 5-14 events/hour), moderate (AHI 15-29 events/hour) or severe (AHI $\geq 30$ events/hour) (27). Patients with $\mathrm{PaCO}_{2}>45 \mathrm{mmHg}$ were diagnosed as OHS after ruling out other disorders that may cause alveolar hypoventilation. $\mathrm{NH}$ was considered when sleep time spent with $\mathrm{SpO}_{2}<90 \%$ was $\geq 30 \%$ of the total sleep time. Serum uric acid level was measured in the blood sample taken in the morning of the sleep study. High serum uric acid level was defined as levels of serum uric acid $>6.8 \mathrm{mg} / \mathrm{dL}$ in males and $>6.0 \mathrm{mg} / \mathrm{dL}$ in females (28).

The study was carried out according to the principles of the Helsinki Declaration. Written informed consent was obtained from all patients. The study was approved by the Institutional Board of Istanbul University (Ethic No: 15.01.2021/68).

\section{Statistical analysis}

SPSS 21.0 software (AIMS, Istanbul, Turkey) was used for statistical analysis. Continuous variables were presented as mean \pm SD and categorial variables as percentage. Nonparametric tests were used when the data were not normally distributed. Normal distribution of variables was calculated with the Shapiro-Wilk test. A Chi-square test was used for categorical variables. Group comparisons were performed with Student's t-test or Mann-Whitney's U test. One-way Anova was used for the comparison of groups of more than two. The relationship between the levels of uric acid and demographics, anthropometric measurements and polysomnographic data was analyzed with Spearman correlation. Logistic regression analysis was performed to determine the factors related to uric acid levels. A p value $<0.05$ was considered statistically significant.

\section{RESULTS}

In this study 170 subjects with $\mathrm{BMI} \geq 30 \mathrm{~kg} / \mathrm{m}^{2}$ were evaluated. Polysomnography revealed 11 subjects without SRBD. We excluded these subjects and performed analysis on 159 subjects with SRBD (79 females, 80 males, age: $50.0 \pm 10.5$ years). The mean BMI was $40.1 \pm 5.7 \mathrm{~kg} / \mathrm{m}^{2}$. Of subjects, $37.7 \%(n=60)$ had class III obesity $\left(\geq 40 \mathrm{~kg} / \mathrm{m}^{2}\right)$. Most of the subjects had comorbidities (83.6\%, $n=133$ ). The most common comorbidities were hyperlipidemia $(n=94,59.1 \%)$, hypertension $(n=76,47.8 \%)$, and diabetes mellitus ( $n=62,38.9 \%)$. Of these 159 patients, 83 (52.2\%) had pure OSA and 76 (47.8\%) had OHS. Of the OHS subjects, three did not have OSA and the remaining had OSA. NH was detected in $25.8 \%(n=41)$ of 159 subjects. Demographics, spirometric measurements, ABG analysis, polysomnographic data and uric acid levels of OSA and OHS subjects are given in Table 1. Uric acid levels were similar among patients with OHS and pure OSA (Table 1). When we compare the data of patients with OHS and OSA subgroups, uric acid levels and the frequency of $\mathrm{NH}$ were higher in subjects with $\mathrm{OHS}$ than mild-mod- 
Table 1: Demographics, spirometric measurements, arterial blood gas analysis, polysomnographic data, and uric acid levels of OSA and OHS subjects

\begin{tabular}{|c|c|c|c|}
\hline & $\begin{array}{c}\text { OSA } \\
(n=83)\end{array}$ & $\begin{array}{l}\text { OHS } \\
(n=76)\end{array}$ & $\begin{array}{c}\mathrm{p} \\
\text { value }\end{array}$ \\
\hline Age & $49.4 \pm 10.7$ & $50.6 \pm 10.3$ & 0.5 \\
\hline Gender (Female/Male) & $47 / 36$ & $32 / 44$ & 0.8 \\
\hline $\mathrm{BMI}\left(\mathrm{kg} / \mathrm{m}^{2}\right)$ & $38.7 \pm 4.2$ & $41.6 \pm 6.6$ & 0.001 \\
\hline Neck circumference $(\mathrm{cm})$ & $39.9 \pm 3.4$ & $42.5 \pm 4.1$ & $<0.001$ \\
\hline Waist/hip ratio & $0.9 \pm 0.1$ & $1 \pm 0.1$ & 0.2 \\
\hline Comorbidities (\%) & 81.9 & 85.5 & 0.7 \\
\hline Daytime $\mathrm{PaO}_{2}(\mathrm{mmHg})$ & $81.8 \pm 8.1$ & $74.2 \pm 8.5$ & $<0.001$ \\
\hline Daytime $\mathrm{PaCO}_{2}(\mathrm{mmHg})$ & $41.6 \pm 2.2$ & $48.6 \pm 4.0$ & $<0.001$ \\
\hline $\mathrm{FEV}_{1}(\%)$ & $100.4 \pm 18.6$ & $95.6 \pm 18.1$ & 0.1 \\
\hline FVC (\%) & $101.7 \pm 17.5$ & $96.4 \pm 17.2$ & 0.06 \\
\hline AHI (events/hour) & $34 \pm 21.9$ & $45.5 \pm 30.9$ & 0.008 \\
\hline ODI (events/hour) & $33 \pm 23.8$ & $53 \pm 31.7$ & $<0.001$ \\
\hline Mean $\mathrm{SpO}_{2}(\%)$ & $94.4 \pm 2.2$ & $90.6 \pm 7.2$ & $<0.001$ \\
\hline Lowest $\mathrm{SpO}_{2}(\%)$ & $78.6 \pm 9.9$ & $65.9 \pm 17.6$ & $<0.001$ \\
\hline $\begin{array}{l}\text { Sleep time with } \mathrm{SpO}_{2} \\
<90 \%(\%)\end{array}$ & $9.6 \pm 16.1$ & $29.2 \pm 30.3$ & $<0.001$ \\
\hline Uric acid (ng/mL) & $5.7 \pm 1.7$ & $5.9 \pm 1.3$ & 0.4 \\
\hline Hyperuricemia (\%) & 32.5 & 28.9 & 0.7 \\
\hline
\end{tabular}

AHI: apnea hypopnea index; BMI: body mass index; FEV1: forced expiratory volume 1. second; FVC: forced vital capacity; ODI: oxygen desaturation index; OHS: obesity hypoventilation syndrome; OSA: obstructive sleep apnea; $\mathrm{PaO}_{2}$ : partial arterial oxygen pressure; $\mathrm{PaCO}_{2}$ : partial arterial carbon dioxide pressure; $\mathrm{SpO}_{2}$ : arterial oxygen saturation measured by pulse oximetry

erate OSA (respectively, $5.9 \pm 1.3 \mathrm{mg} / \mathrm{dl}$ vs. $5.3 \pm 1.5 \mathrm{mg} / \mathrm{dl}$, $p=0.018 ; 39.5 \%$ vs. $6.9 \%, p<0.001)$. However, uric acid levels and the frequency of $\mathrm{NH}$ were similar in subjects with OHS compared to severe OSA (respectively, $5.9 \pm 1.3 \mathrm{mg} /$ $d$ vs. $6.19 \pm 1.8 \mathrm{mg} / \mathrm{dl}, \mathrm{p}=0.38 ; 39.5 \%$ vs. $20.5 \%, p=0.06$ ).

For all obese patients with SRBD, uric acid levels were higher in patients with $\mathrm{NH}$ than without $\mathrm{NH}(6.22 \pm 1.37$ $\mathrm{mg} / \mathrm{dl}, 5.67 \pm 1.51 \mathrm{mg} / \mathrm{dl}, \mathrm{p}=0.008)$. Differences between obese subjects with and without NH are given in Table 2 .

For subjects with pure OSA, 47\% $(n=39)$ had severe OSA, $33.7 \%(n=28)$ had moderate OSA and 19.3\% $(n=16)$ had mild OSA. Of the OSA subjects, uric acid levels were high$\mathrm{er}$ in males than females $(6.86 \pm 1.64 \mathrm{mg} / \mathrm{dl}$ vs. $4.84 \pm 1.10$ $\mathrm{mg} / \mathrm{dl}, \mathrm{p}<0.001)$. Uric acid levels were not different between subjects with and without severe obesity $(5.27 \pm 1.47$ $\mathrm{mg} / \mathrm{dlvs} .5 .89 \pm 1.73 \mathrm{mg} / \mathrm{dl}, \mathrm{p}=0.13)$. Uric acid levels were similar among subjects with and without comorbidities $(5.78 \pm 1.78 \mathrm{mg} / \mathrm{dl}$ vs. $5.45 \pm 1.18 \mathrm{mg} / \mathrm{dl}, \mathrm{p}=0.499)$. Uric acid
Table 2: Differences between subjects with and without nocturnal hypoxemia $(\mathrm{NH})$

\begin{tabular}{|c|c|c|c|}
\hline & $\begin{array}{c}\text { Subjects } \\
\text { with NH } \\
(n=41)\end{array}$ & $\begin{array}{c}\text { Subject } \\
\text { without } \\
\text { NH } \\
(n=118)\end{array}$ & $p$ value \\
\hline Age & $50.04 \pm 12.62$ & $49.98 \pm 9.71$ & 0.9 \\
\hline $\begin{array}{l}\text { Gender (Female/ } \\
\text { Male) }\end{array}$ & $15 / 26$ & $64 / 54$ & 0.07 \\
\hline BMI $\left(\mathrm{kg} / \mathrm{m}^{2}\right)$ & $41.82 \pm 7.21$ & $39.51 \pm 4.93$ & 0.02 \\
\hline $\begin{array}{l}\text { Neck circumfer- } \\
\text { ence }(\mathrm{cm})\end{array}$ & $43.26 \pm 4.20$ & $40.44 \pm 3.62$ & $<0.001$ \\
\hline Waist/hip ratio & $0.98 \pm 0.08$ & $0.94 \pm 0.08$ & 0.005 \\
\hline Comorbidities (\%) & 87.8 & 82.2 & 0.5 \\
\hline $\begin{array}{l}\text { Daytime } \mathrm{PaO}_{2} \\
(\mathrm{mmHg})\end{array}$ & $71.85 \pm 8.86$ & $80.35 \pm 8.15$ & $<0.001$ \\
\hline $\begin{array}{l}\text { Daytime } \mathrm{PaCO}_{2} \\
(\mathrm{mmHg})\end{array}$ & $48.43 \pm 5.86$ & $43.75 \pm 3.53$ & $<0.001$ \\
\hline AHI (events/hour) & $65.32 \pm 27.52$ & $30.52 \pm 20.39$ & $<0.001$ \\
\hline ODI (events/hour) & $73.90 \pm 26.23$ & $31.66 \pm 21.79$ & $<0.001$ \\
\hline Mean $\mathrm{SpO}_{2}(\%)$ & $86.43 \pm 7.89$ & $94.69 \pm 1.68$ & $<0.001$ \\
\hline Lowest $\mathrm{SpO}_{2}(\%)$ & $56.12 \pm 17.33$ & $78.22 \pm 9.61$ & $<0.001$ \\
\hline $\begin{array}{l}\text { Sleep time with } \\
\mathrm{SpO}_{2}<90 \%(\%)\end{array}$ & $58.26 \pm 19.14$ & $5.33 \pm 6.77$ & $<0.001$ \\
\hline Uric acid (ng/mL) & $6.22 \pm 1.37$ & $5.67 \pm 1.51$ & 0.008 \\
\hline Hyperuricemia (\%) & 46.34 & 25.42 & 0.018 \\
\hline
\end{tabular}

AHI:apnea hypopnea index; BMI: body mass index; $\mathrm{NH}$ : nocturnal hypoxemia; ODI: oxygen desaturation index; OHS: obesity hypoventilation syndrome; OSA: obstructive sleep apnea; $\mathrm{PaO}_{2}$ : partial arterial oxygen pressure; $\mathrm{PaCO}_{2}$ : partial arterial carbon dioxide pressure; $\mathrm{SpO}_{2}$ : arterial oxygen saturation measured by pulse oximetry

levels were not different between subjects with and without hypertension $(5.89 \pm 2.1 \mathrm{mg} / \mathrm{dl}$ vs. $5.58 \pm 1.26 \mathrm{mg} / \mathrm{dl}$, $\mathrm{p}=0.41)$, diabetes mellitus $(5.82 \pm 2.1 \mathrm{mg} / \mathrm{dl}$ vs. $5.66 \pm 1.41$ $\mathrm{mg} / \mathrm{dl}, \quad \mathrm{p}=0.69)$ and hyperlipidemia $(6.02 \pm 1.92 \mathrm{mg} / \mathrm{dl}$ vs. $5.36 \pm 1.28 \mathrm{mg} / \mathrm{dl}, \mathrm{p}=0.06$ ). Uric acid levels increased as OSA severity increased (mild OSA:5.03 $\pm 1.41 \mathrm{mg} / \mathrm{dl}$, moderate OSA:5.46 $\pm 1.55 \mathrm{mg} / \mathrm{dl}$, severe OSA:6.19 \pm 1.8 $\mathrm{mg} / \mathrm{dl}, \mathrm{p}=0.039)$. Age, BMl and comorbidity rates were similar between groups. As OSA severity increased, male gender dominance also increased. $\mathrm{NH}$ was found in $13.2 \%(n=11)$ of OSA subjects. For patients with OSA, uric acid levels were higher in subjects with $\mathrm{NH}$ than without $\mathrm{NH}(6.69 \pm 1.51 \mathrm{mg} / \mathrm{dl}$ vs. $5.58 \pm 1.67 \mathrm{mg} / \mathrm{dl}, \mathrm{p}=0.025)$. Uric acid levels especially were higher in subjects with severe OSA compared to mild-moderate OSA $(6.19 \pm 1.8$ vs. $5.3 \pm 1.5, p=0.013)$. Demographics, $A B G$ analysis, polysomnographic data and uric acid levels of subjects with different OSA severity are given in Table 3. 
Table 3: Subjects with different obstructive sleep apnea (OSA) severity

\begin{tabular}{|c|c|c|c|}
\hline & $\begin{array}{c}\text { Severe } \\
\text { OSA } \\
(n=39)\end{array}$ & $\begin{array}{l}\text { Mild-mod- } \\
\text { erate OSA } \\
\quad(n=44)\end{array}$ & $\begin{array}{c}\mathrm{p} \\
\text { value }\end{array}$ \\
\hline Age & $50.7 \pm 10.6$ & $48.3 \pm 10.8$ & 0.29 \\
\hline Gender (Female/Male) & $17 / 22$ & $30 / 14$ & 0.028 \\
\hline $\operatorname{BMI}\left(\mathrm{kg} / \mathrm{m}^{2}\right)$ & $39 \pm 3.9$ & $38.4 \pm 4.5$ & 0.48 \\
\hline $\begin{array}{l}\text { Neck circumference } \\
(\mathrm{cm})\end{array}$ & $41.3 \pm 3.2$ & $38.7 \pm 3.2$ & 0.001 \\
\hline Waist/hip ratio & $0.96 \pm 0.1$ & $0.93 \pm 0.1$ & 0.11 \\
\hline Comorbidities (\%) & 82 & 81.8 & 0.9 \\
\hline $\mathrm{NH}(\%)$ & 20.5 & 6.8 & 0.1 \\
\hline Daytime $\mathrm{PaO}_{2}(\mathrm{mmHg})$ & $80.5 \pm 6.5$ & $82.9 \pm 9.3$ & 0.16 \\
\hline $\begin{array}{l}\text { Daytime } \mathrm{PaCO}_{2} \\
(\mathrm{mmHg})\end{array}$ & $41.8 \pm 2.2$ & $41.5 \pm 2.2$ & 0.51 \\
\hline AHI (events/hour) & $53.4 \pm 16.0$ & $16.8 \pm 6.4$ & $<0.001$ \\
\hline ODI (events/hour) & $52.4 \pm 20.6$ & $16.7 \pm 10.2$ & $<0.001$ \\
\hline Mean $\mathrm{SpO}_{2}(\%)$ & $93.7 \pm 2.3$ & $95.0 \pm 2.0$ & $<0.003$ \\
\hline Lowest $\mathrm{SpO}_{2}(\%)$ & $74.1 \pm 11.3$ & $82.5 \pm 6.6$ & $<0.001$ \\
\hline $\begin{array}{l}\text { Sleep time with } \\
\mathrm{SpO}_{2}<90 \% \text { (\%) }\end{array}$ & $12.7 \pm 14.4$ & $6.9 \pm 17.2$ & $<0.001$ \\
\hline Uric acid (ng/mL) & $6.19 \pm 1.8$ & $5.3 \pm 1.5$ & 0.013 \\
\hline Hyperuricemia (\%) & 43.6 & 22.7 & 0.06 \\
\hline
\end{tabular}

AHI: apnea hypopnea index; BMI: body mass index;

$\mathrm{NH}$ : nocturnal hypoxemia; ODI: oxygen desaturation index; OHS: obesity hypoventilation syndrome; OSA: obstructive sleep apnea; $\mathrm{PaO}_{2}$ : partial arterial oxygen pressure; $\mathrm{PaCO}_{2}$ : partial arterial carbon dioxide pressure; $\mathrm{SpO}_{2}$ : arterial oxygen saturation measured by pulse oximetry

\section{Correlations for uric acid levels}

For all patients with SRBD, uric acid levels were correlated with neck circumference $(r=0.366, p<0.001)$, waist/hip ratio $(r=0.358, p<0.001)$, OSA severity $(r=0.224, p=0.005)$, AHI ( $r=0.250, p=0.001), \mathrm{ODI}(r=291, p<0.001)$, mean $\mathrm{SpO}_{2}$ $(r=-0.198, p=0.013)$, lowest $\mathrm{SpO}_{2}(r=-0.204, p=0.01)$ and sleep time spent with $\mathrm{SpO}_{2}<90 \%(r=0.228, p=0.004)$. Male gender, waist/hip ratio and $\mathrm{NH}$ were factors independently related with uric acid levels in regression analysis (retrospectively; $p<0.001, p=0.03, p=0.03$ ).

\section{DISCUSSION}

In our study population of obese patients with SRBD, we found that serum levels of uric acid were higher in patients with $\mathrm{NH}$ and higher in severe OSA. Male gender, waist/hip ratio and $\mathrm{NH}$ were factors independently related with uric acid levels.

In the literature there are studies that investigated serum levels of uric acid in patients with OSA. These studies re- ported an association between OSA and high uric acid levels (13-25). However, there are only a few studies evaluating the association between levels of uric acid and OSA severity or $\mathrm{NH}(14,15,19)$.

To the best our knowledge, this is one of the few studies that found a correlation between uric acid levels and $\mathrm{NH}$ in patients with SRBD. Similarly, Hira et al. reported that serum uric acid values correlated significantly with oxygen saturation percentage of total sleep time spent below 95\% (14). In our study, uric acid levels were correlated with nocturnal mean saturation, lowest saturation and sleep time spent with $\mathrm{SpO}_{2}<90 \%$.

Apneas during sleep cause a decrease in arterial oxygen saturation and tissue hypoxia. For this reason, it is expected that uric acid levels should increase in patients with OSA, especially severe OSA. In line with this, uric acid levels were correlated with $\mathrm{AHI}$ and ODI in our study. In contrast, there was no correlation between uric acid and $\mathrm{AHI}$ in the study of Hira (14). The exact biological mechanism underlying an association between the sleep variables and high serum uric acid is not clear. The hypothesized mechanism is that during hypoxia, the production of adenosine triphosphate (ATP) from adenosine diphosphate (ADP) is impaired, leading to a net degradation of ATP to ADP and adenosine monophosphate. This cascade leads to the release of intermediates of purine nucleotide (adenosine, inosine, hypoxanthine and xanthine). Uric acid is biosynthesized from these purine catabolic products and is the end product of ATP degradation. It increases in body fluids in the case of increased anaerobic metabolism induced by cellular hypoxia (1-3). In a cross-over study of 10 men exposed to six hours of intermittent hypoxia for four days, it was shown that there is an increase in uric acid production during the four days of intermittent hypoxia. It was suggested that this elevation in uric acid reflects the production of reactive oxygen species through the xanthine oxidase pathway (29). This study shows that reactive oxygen species overproduction modulates increased acute hypoxic ventilatory response. These mechanisms may be responsible for increased acute hypoxic ventilatory response in patients with OSA. So, the correlation between OSA and uric acid might have been mainly due to $\mathrm{NH}$ and intermittent hypoxemia.

Since uric acid is a marker of tissue hypoxia, it should increase in patients with OHS. However, there is no other study that investigated uric acid levels in patients with $\mathrm{OHS}$. Our study is the first one and we found that uric acid levels were not different in subjects with and without $\mathrm{OHS}$. Additionally, uric acid levels were not correlated with $\mathrm{PaCO}_{2}$ in our study. On the other hand, uric acid levels were not higher in patients with $\mathrm{OHS}$ compared to patients with pure severe OSA. This result may be because of similar frequency of patients with $\mathrm{NH}$ in both groups of pure severe OSA and 
OHS. Since there is no study to compare our results, this issue needs to be investigated in further studies.

Sunnetcioglu et al. reported that elevated levels of serum uric acid were associated with OSA severity (15). Similarly, in our study, serum uric acid levels were elevated in obese subjects with $\mathrm{NH}$ and severe OSA. Sunnetcioglu et al. did not investigate the relationship between serum uric acid levels and $\mathrm{OHS}$ and all of their patients were not obese.

Seetho et al. reported that OSA was associated with serum urate in severe obesity (13). According to the study of Seetho, there is evidence of an association between OSA and uric acid in severely obese females. Curiously, we found that male gender was an independently related factor for hyperuricemia in obese subjects with SRBD. In another study, Plywaczewski et al. showed that hyperuricemia is frequent in males with OSA (25).

Pływaczewski et al. reported that elevated uric acid levels are related to extreme obesity. But we found that uric acid levels were not different between subjects with and without malign obesity. Even though neck circumference and waist/ hip ratio were found to be related to uric acid levels, there was not a correlation between BMI and levels of uric acid.

It has been shown that hyperuricemia is associated with hypertension, diabetes mellitus, peripheral artery disease and cardiovascular disease (4-7). These comorbidities are frequent in patients with SRBD. Hyperuricemia associated with the sleep variables may also be affected by the increased risk of cardiovascular disease seen in SRBD. However, elevated uric acid levels were not related to a higher prevalence of hyperlipidemia, diabetes mellitus and hypertension in our study.

This study has several strengths, including high quality, standardized data collection. This study is the first study investigating the relationship between serum uric acid levels and OHS. Nevertheless, there are limitations. It would be better including a healthy non-OSA control group or a non-obese group. The sample size of our study was relatively small. With a larger sample size, there might be a difference between patients with or without $\mathrm{OHS}$ in the case of uric acid levels.

In summary, this study shows a positive association between uric acid levels and male gender, OSA severity, and $\mathrm{NH}$ in patients with SRBD. Uric acid, as a marker of tissue hypoxia, may be useful in defining higher risk groups in obese patients with SRBD. Further prospective studies investigating uric acid levels in subjects with $\mathrm{OHS}$ are needed.

Ethics Committee Approval: This study was approved by the Ethical Committee of the Istanbul University, Istanbul Faculty of Medicine (Date:15.01.2021, No:68).
Informed Consent: Written consent was obtained from the participants.

Peer Review: Externally peer-reviewed.

Author Contributions: Conception/Design of Study- Z.B., E.K.; Data Acquisition- A.P., Z.B.; Data Analysis/Interpretation- Z.B.; Drafting Manuscript- A.P.; Critical Revision of Manuscript- Z.B., E.K.; Final Approval and Accountability- A.P.

Conflict of Interest: Authors declared no conflict of interest.

Financial Disclosure: Authors declared no financial support.

Etik Komite Onayı: Bu çalışma için etik komite onayı İstanbul Üniversitesi, İstanbul Tıp Fakültesi Etik Kurulu'ndan alınmıştır (Tarih:15.01.2021, Sayı:68).

Bilgilendirilmiş Onam: Katılımcılardan bilgilendirilmiş onam alınmıştır.

Hakem Değerlendirmesi: Dış bağımsız.

Yazar Katkıları: Çalışma Konsepti/Tasarım- Z.B., E.K.; Veri Toplama- A.P., Z.B.; Veri Analizi/Yorumlama- Z.B.; Yazı Taslağı- A.P.; İçeriğin Eleştirel İncelemesi- Z.B., E.K.; Son Onay ve SorumlulukA.P.

Çıkar Çatışması: Yazarlar çıkar çatışması beyan etmemişlerdir.

Finansal Destek: Yazarlar finansal destek beyan etmemişlerdir.

\section{REFERENCES}

1. Saito H, Nishimura M, Shibuya E, Makita H, Tsujino I, Miyamoto K, et al. Tissue hypoxia in sleep apnea syndrome assessed by uric acid and adenosine. Chest 2002;122(5):1686-94. [CrossRef]

2. Rodwell VW. Metabolism of Purine and Pyrimidine Nucleotides. In: Murray RK, Granner DK, Rodwell WW, editors. Harper's Illustrated Biochemistry. 27th ed. Singapore: McGraw-Hill Education (Asia); 2006. p. 301-10.

3. Braghiroli A, Sacco C, Erbetta M, Ruga V, Donner CF. Over night urinary uric acid: creatinine ratio for detection of sleep hypoxemia. Validation study in chronic obstructive pulmonary disease and obstructive sleep apnea before and after treatment with nasal continuous positive airway pressure. Am Rev Respir Dis 1993;148(1):173-8. [CrossRef]

4. Janghorbani M, Ghanbari H, Aminorroaya A, Amini M. Relationship Between Serum Uric Acid and Incident Hypertension in Patients with Type 2 Diabetes. Rev Diabet Stud 2018;14(4):354-63. [CrossRef]

5. Ekici B, Kütük U, Alhan A, Töre HF. The relationship between serum uric acid levels and angiographic severity of coronary heart disease. Kardiol Pol 2015;73(7):533-8. [CrossRef]

6. Fouad M, Fathy $H$, Zidan A. Serum uric acid and its association with hypertension, early nephropathy and chronic kidney disease in type 2 diabetic patients. J Bras Nefrol 2016;38(4):403-10. [CrossRef]

7. Shankar A, Klein BE, Nieto FJ, Klein R. Association between serum uric acid level and peripheral arterial disease. Atherosclerosis 2008;196(2):749-55. [CrossRef] 
8. Gonzaga C, Bertolami A, Bertolami M, Amodeo C, Calhoun D. Obstructive sleep apnea, hypertension and cardiovascular diseases. J Hum Hypertens 2015;29(12):70512. [CrossRef]

9. Bouzerda A. Risque cardiovasculaire et syndrome d'apnées obstructives du sommeil Pan Afr Med J 2018;29:47. [CrossRef]

10. Dredla BK, Castillo PR. Cardiovascular Consequences of Obstructive Sleep Apnea. Curr Cardiol Rep 2019;21(11):137. [CrossRef]

11. Kheirandish-Gozal L, Gozal D. Obstructive Sleep Apnea and Inflammation: Proof of Concept Based on Two Illustrative Cytokines. Int J Mol Sci 2019;20(3):459. [CrossRef]

12. Drager LF, Togeiro SM, Polotsky VY, Lorenzi-Filho G. Obstructive sleep apnea: a cardiometabolic risk in obesity and the metabolic syndrome. J Am Coll Cardiol 2013;62(7):569-76. [CrossRef]

13. Seetho IW, Parker RJ, Craig S, Duffy N, Hardy KJ, Wilding JP, et al. Serum urate and obstructive sleep apnoea in severe obesity. Chron Respir Dis 2015;12(3):238-46. [CrossRef]

14. Hira HS, Shukla A, Kaur A, Kapoor S. Serum uric acid and lactate levels among patients with obstructive sleep apnea syndrome: which is a better marker of hypoxemia? Ann Saudi Med 2012;32(1):37-42. [CrossRef]

15. Sunnetcioglu A, Gunbatar H, Yıldız H. Red cell distribution width and uric acid in patients with obstructive sleep apnea. Clin Respir J 2018;12(3):1046-52. [CrossRef]

16. Zheng C, Song H, Wang S, Liu J, Lin T, Du C, et al. Serum Uric Acid Is Independently Associated with Risk of Obstructive Sleep Apnea-Hypopnea Syndrome in Chinese Patients with Type 2 Diabetes. Dis Markers 2019;2019:4578327. [CrossRef]

17. Sari O, Akpak YK, Yerebasmaz N, Arslan I, Dagcioglu BF, Oral S. Evaluation of obstructive sleep apnea prevalence in mothers of infants with low birth weight and its relationship with serum uric acid levels as a hypoxia marker. J Matern Fetal Neonatal Med 2020:1-8. [CrossRef]

18. Lai CH, Huang RJ, Wong JK, Chang SW, Chung AH, Chi $Y C$, et al. Confounded by obesity and modulated by urinary uric acid excretion, sleep-disordered breathing indirectly relates to hyperuricaemia in males: A structural equation model. J Sleep Res 2020:e13108. [CrossRef]

19. Bouloukaki I, Mermigkis C, Tzanakis N, Kallergis E, Moniaki $\checkmark$, Mauroudi E, et al. Evaluation of Inflammatory Markers in a Large Sample of Obstructive Sleep Apnea Patients without Comorbidities. Mediators Inflamm 2017;2017:4573756. [CrossRef]
20. Fleming WE, Holty JC, Bogan RK, Hwang D, Ferouz-Colborn AS, Budhiraja R, et al. Use of blood biomarkers to screen for obstructive sleep apnea. Nat Sci Sleep 2018;10:159-67. [CrossRef]

21. Chen Q, Lin G, Chen L, Huang J, Huang Y, Li P, et al. Does Continuous Positive Airway Pressure Therapy in Patients with Obstructive Sleep Apnea Improves Uric Acid? A Meta-Analysis. Oxid Med Cell Longev 2019;2019:4584936. [CrossRef]

22. Shi T, Min M, Sun $C$, Cheng $C$, Zhang $Y$, Liang $M$, et al. A meta-analysis of the association between gout, serum uric acid level, and obstructive sleep apnea. Sleep Breath 2019;23(4):1047-57. [CrossRef]

23. Kanbay A, Inonu H, Solak Y, Erden A, Uslu E, Yuksel SA, et al. Uric acid as a potential mediator of cardiovascular morbidity in obstructive sleep apnea syndrome. Eur J Intern Med 2014;25(5):471-6. [CrossRef]

24. Kosacka M, Brzecka A, Piesiak P, Korzeniewska A, Jankowska R. Soluble ligand CD40 and uric acid as markers of atheromatosis in patients with obstructive sleep apnea. Adv Exp Med Biol 2015;839:55-60. [CrossRef]

25. Pływaczewski R, Bednarek M, Jonczak L, Górecka D, Sliwińiski P. [Hyperuricaemia in males with obstructive sleep apnoea (osa)]. Pneumonol Alergol Pol 2005;73(3):254-9.

26. Miller MR, Hankinson J, Brusasco $V$, et al. ATS/ERS Task Force. Standardisation of spirometry. Eur Respir J 2005;26(2):319-38. [CrossRef]

27. Berry RB, Brooks R, Gamaldo CE, et al. The AASM Manual forthe Scoring of Sleep and Associated Events: Terminology and Technical Specifications. Version 2.0.2. Darien, IL: AmericanAcademy of Sleep Medicine; 2013. www.aasmnet. org

28. Wiener RC, ShankarA. Association between SerumUric Acid Levels and Sleep Variables: Results from the National Health and Nutrition Survey 2005-2008. Int J Inflam 2012;2012:363054. [CrossRef]

29. Pialoux V, Hanly PJ, Foster GE, Brugniaux JV, Beaudin AE, Hartmann SE, et al. Effects of exposureto intermittent hypoxia on oxidative stress and acute hypoxic ventilatory response in humans. Am J Respir Crit Care Med 2009;180(10):1002-9. [CrossRef] 